In intra venous injection or $1 . \mathrm{I}^{\circ}$. + intra tracheal injection in swine might kill the animal when the amount of microorganisms is large. The discase is septiccnic without any pulmonary localization.

To " fix " Pasteuvella inside the lungs they should be damaged previously. P. multocida is well known as an "opportunist" invading the breached tissues. Therefore, we choosed the administration of embryonated Ascaris sum eggs 7 to 8 days before the trial.

Ascaris + Pasteuvella given by nebulization: (particle size $\mathrm{I}$ to $3 \mu$ ) the characteristics of the discase were : severe respiratory symptoms with high hyperthermia, ... polyarthritis (the septicemic facet of Pasteurella), - a loss in weight and an acute broncho pneumonia with an average death time of 1.5 clays.

Ascaris + Pasteurella given by intra tracheal (and I.V.) route: the same disease was obtained, but without polyarthritis. The acute broncho pneumonia was severe and death occurred 4 to 8 days after and was dose-related.

Emphasis must be laid on the difficulty of reproducing in the laboratory a disease so commonly found in the field, as the purpose was to obtain a regular course and not a too carly mortality.

\title{
The extent of Transmissible Gastro Enteritis among pigs in France
}

\author{
J. P. IAABADIE (1), J. M. AYNAUD (2), I. RENAUIT (1), \\ J. VAISSAIRIi (') et CI. MAIRE (') \\ (1) Laboratoives vétérinaives Sanders, \\ 17. quai de l'Industrie, 9 I200 Athis-Mons (France) \\ (2) Laboratoive de Pathologie porcine \\ I.N.R.A., $7885^{\circ}$ Thiverval-Grignon (France)
}

The extent of transmissible gastro enteritis in France is demonstrated in this paper. A study was made during one year and concerned I 9 piglets and 308 sera of piglets and sows fron 82 herds and 23 departments. The disease had classical (95\% of positive subjects) or subacute (66\% of positive subjects) form. The serological survey concerning 31 herds and 200 sera of sows showed 77 per cent of positive subjects in the suspicious herds and 46 per cent in the apparently healthy herds.

\section{Effect of the watering method on the health of pigs}

Josée VAISSATRE $\left({ }^{1}\right)$, A. GOTKOVSKY $\left({ }^{2}\right)$, D. DANSETIE (2)

L. RENAULT (1), Cl. MAIRE (1), J.-P. LABADIE (1) et Y, MAURY (3)

\section{(1) Laboratoive Vétérinaive}

(2) Bureau d'Etudes, Service Porc,

(3) Service Etudes et Formulation,

SANDERS r7, quai de l'Industrie, 9I200 Athis-Mons (France)

According to two surveys made on a total of $4 \mathrm{I} 7$ pigs from 268 farms, the authors show the importance of renal disorders in this species and the necessity of a suitable watering system adapted to the age of the animals. 47 per cent of the automatic water bowls were defective in farrowing-houses and 65 per cent in post weaning houses. These incorrect waterings led to high urea levels in the animals favouring for instance the occurrence of various digestive disorders in the herds. The best watering system seems to be a flexible paddle and a rather flat bowl. 